\title{
Enkele opmerkings oor die godsdienstig- teologiese insigte wat na vore kom in die Gelofte van 1838 en daarna by die onderhouding daarvan
}

\author{
Prof A D Pont
}

Emeritus-professor

Departement Kerkgeskiedenis, Universiteit van Pretoria

\begin{abstract}
“... en dat wy den dag der overwinning in een boek zullen aantekenen om dezelve bekendte maken zelfs aan onze laatste nageslachten, op dat het ter ere van God gevierd mag worden."
\end{abstract}

Jan Bantjes, Journaal, Des 1838

\begin{abstract}
Some remarks on the theological insights on the Voortrekker Vow of (16 December) 1838 which contributed to the continued honouring of the Vow

In this study it is noted that after the Battle of Colenso on 15 December 1899 and the Battle of Nooitgedacht on 13 December 1900, the Boer commandos held special meetings to commemorate the Voortrekker Vow of 1838 and the victory at Blood River. The question is asked what the theological background can be. When the Voortrekker Vow of 1838 is studied it becomes clear that the taking of the Vow was possible in the context of the Calvinist orthodoxy, influenced by the Nadere Reformatie of the $17^{\text {th }}$ Century. This was more or less the accepted theology of the Voortrekkers sustained by the Statenbijbel and the books of the Nadere Reformatie theologians.
\end{abstract}

\section{INLEIDING}

By die herdenking van die uitbreek van die Tweede Vryheidsoorlog van 1899 tot 1902 en die nagaan van daardie geskiedenis het dit opgeval dat die onderhouding en herdenking 
van die Gelofte van 1838 nie tydens die oorlog verwaarloos is nie. Dit dui daarop dat die Gelofte van 1838 'n besondere plek in die denke en lewensbeskouing van die republikeinse Afrikaner aan die einde van die $19 \mathrm{e}$ en die begin van die $20 \mathrm{e}$ eeu gehad het. Dit het ongetwyfeld saamgehang met die waarneembare werklikheid dat die Afrikaner van destyds se denke vir 'n baie groot deel deur sy geloof in die lewende God bepaal is.' In hierdie navorsing word gepoog, al is die beperk vanweë die gebrek aan materiaal, om 'n beeld te probeer vorm van daardie godsdienstig-teologiese insigte. Dit is opvallend dat na die oorlog van 1899-1902 as die Afrikaner tot die bedelstaf toe verarm is, as hy onderwerp word aan 'n massiewe aanslag om te verengels en hy verdeeld is vanweë die optrede van die Boeregeneraals Louis Botha en Jan Smuts, ${ }^{2}$ dat dan die onderhouding van die Gelofte nie 'n groot plek in die Afrikaner se lewe inneem nie. ${ }^{3}$ Die situasie word nie verbeter nie wanneer in 1910 die Afrikaner uit die voormalige ZAR en OVS ingesluit word in die Unie nie. Dan word die eiesoortigheid van die Afrikaner medebepaal deur die Afrikaanstaliges in die Kaapkolonie en Natal.

Geleidelik het, na die aanvanklike onsekerheid, Geloftedag in die dertigerjare van die vorige eeu weer 'n betekenis in die lewe van die Afrikanervolk gekry. Maar daardie stuk geskiedenis lê buite die gesigsveld van hierdie studie. Dit gaan hier om die

\footnotetext{
${ }^{1}$ Hierdie stelling berus op ' $\mathrm{n}$ algemene indruk wat gevorm is deur die lees en nagaan van oorlogsdagboeke, oorlogsherinneringe, amptelike verslae en selfs amptelike telegramme. In die breè kan, byvoorbeeld, pres Kruger se toesprake nagelees word om 'n indruk te kry hoe die Bybel en Bybelse voorbeelde sy taal en denkbeelde bepaal het. ' $n$ Indruk van die inhoud en rigting van pres Kruger se toesprake kan verkry word by Du Plessis (1952).

${ }^{2}$ Vergelyk Kruger (1960:viii-x). Vergelyk veral die toesprake van Botha en Smuts wat hier aangehaal word (kyk ook Engelenburg 1928:100, 105 e a); vgl ook Brieven van Oom Sarel in De Hervormer, 15 Dec 1910.

${ }^{3}$ In De Hervormer, 15 Dec 1909, skryf neef Willem aan oom Sarel: "als daar een zaak is, die gevaar loopt om helemaal te niet te gaan, dan is dit, in mijn opinie, Dingaansdag. Wat is Dingaansdag toch eigenlijk Het antwoord is gewoonlik gelijkluidend: een nationaal-godsdienstige dag. ... Laat ons nooit vergeten dat wij nu die dag eigenlijk nooit meer kunnen vieren, na de Republikeinse opvatting van voor de oorlog ...." Dan koppel neef Willem die Gelofte van 1838 baie duidelik aan Paardekraal 1880 en sê dan: "Nu, Oom Sarel, wat volgt daaruit? Dit: dat de geestelijke belofte van die dag niet alleen is voor de overwinning op Dingaan, maar ook op Engeland." Dan betoog neef Willem dat dit alles om herbesinning roep. Hy vra dat 16 Desember 'n nasionale (gedenk-)dag moet wees wat 'n godsdienstige inhoud sal hê. Vergelyk $D e$ Hervormer, 15 Feb 1911 waar berig word van 'n Geloftefees in Rustenburg se wêreld en gesê word: "De Heer Visscher zeide dat het een drie werf schande is voor een Afrikaner om 16 December zonder feestviering voorbij te laten gaan." Dit bly opvallend dat Geloftedag in die beginjare van De Hervormer byna geen aandag kry nie.
} 
godsdienstige denkbeelde te peil en om na moontlike bronne ondersoek te doen om vas te stel uit watter dinkwêreld 'n groep mense in die $19 \mathrm{e}$ eeu, die eeu van die groot Verligtheid toe die mens probeer het om beheersend in die middelpunt van sy wêreld te staan, 'n Gelofte aan God maak en dit nie net onderhou nie maar selfs herbevestig.

\section{DIE GELOFTE VAN 1838}

Die Gelofte van 1838 kan aanvanklik maklik geografies vasgepen word. Dit was 'n Gelofte wat Kommodant-Generaal Andries Pretorius se Strafkommando die eerste maal op 9 Desember 1838 by die Wasbankrivier afgelê het. Daarna is dit elke dag in die kommando se godsdiensoefeninge herhaal en ook op 16 Desember 1838 in die laer voor die veldslag ${ }^{4}$.

Die Gelofte as sodanig is 'n merkwaardigheid in die dertigerjare van die $19 \mathrm{e}$ eeu want dit was 'n eeu wat in Europa gekenmerk is deur 'n Verligtheid wat breed gevat het en wat vanuit Nederland ook na die Afrikaner uitgevoer is. ${ }^{5}$ Andersyds was daar 'n opkomende metodistiese stroming wat as 'n teenvoeter vir die rasionalistiese Verligtheid beskou is. ${ }^{6}$ Die twee antroposentriese teologiese stromings het met mekaar meegeding om die grondliggende Calvinistiese ortodoksie met 'n meerdere of mindere bevindelike inslag, uit die denke van die Afrikanergelowige te verwyder. Die Calvinistiese ortodoksie wat vanaf die vestiging van die Kolonie aan die Kaap die hoof teologiese stroom in die Kaapse kerk verteenwoordig het, is veral deur die geskrifte van die oude schrijvers lank lewend gehou. Juis daardie geskrifte het 'n groot rol gespeel om die teologiesgodsdienstige opvattings van die gelowiges aan die Kaap te bepaal. ${ }^{7}$

\footnotetext{
4 Vergelyk onder andere Preller (1918:187). Kyk ook die Journaal van J G Bantjes wat onder andere gepubliseer is in De Zuid-Afrikaan van 14 Junie 1839.

5 Kyk in hierdie verband Pont (s a:14, 160). Daar kan ook aandag gegee word aan Hanekom (1951), veral bl $156 \mathrm{ev}$ waar aangedui word dat spore van die verligte, rasionele rigting reeds in die twintigerjare opgemerk kan word.

6 Die aggressiewe metodisme het eers in die laat vyftigerjare vanuit Amerika na Suid-Afrika oorgewaai, maar voor dit het die bevindelikheid, wat 'n aanhangsel van die Calvinistiese ortodoksie was, al die ordo salutis as 'n noodsaaklike heilsweg voorgehou; kyk weer Pont (a w:160-161).

${ }^{7}$ In hierdie verband kan verwys word na die studie van Van Zijl (s a:200-202). By Van Zyl kan verdere bibliografiese verwysings gevind word.
} 
As nou gelet word op die gebiede waarvandaan die Voortrekkers getrek het en op die daar heersende teologiese rigting, kan gestel word dat die algemene teologiese rigting van die Voortrekkers die Calvinistiese ortodoksie was met 'n duidelike bevindelike inslag soos dit, onder andere, by W à Brakel se Redelyke Godtsdienst van 1700 waargeneem kan word. 8 Dit kan selfs geargumenteer word dat Brakel se werk 'n taamlik algemene aanvaarding gehad het en die dogmatiese handleiding vir die Voortrekkers was. ${ }^{9}$ Dit neem nie weg dat daar 'n hele versameling geskrifte van die oude schrijvers was wat deur die Voortrekkers gelees, bestudeer en toegepas is. As op hulle teologies-godsdienstige leefwêreld gelet word, is dit werklik nie vreemd dat die Voortrekkers in 1838 'n Gelofte afgelê het nie. ${ }^{10}$

As dit gesê word, moet in gedagte gehou word dat die Calvinistiese ortodoksie vanaf die $17 \mathrm{e}$ eeu geleidelik beïnvloed is deur die beweging van die Nadere Reformasie. 'n Beweging wat 'n nadere of verdere reformasie van die lewe beoog het nà die reformasie van die leer. Met die beklemtoning van die lewe van die mens voor God deur 'n ordo salutis het die Nadere Reformasie die verantwoordelikheid van die mens voor God benadruk. Met 'n klem op die leer van die algemene priesterskap van die gelowige en die eis van 'n praktiese vroomheid, met ander woorde ' $n$ vroomheid wat in dade sigbaar word, het die Nadere Reformasie die gelowiges aangespoor om na volmaaktheid en heiligmaking te strewe. Juis hier het die invloed van die puritanisme die sterkste ingewerk en vandaar dat in die Nadere Reformasie daar so 'n duidelike etiese kode was.

Met hierdie klemtone wat deur die woordvoerders en skrywers van die Nadere Reformasie gelê is, het die aksent in die teologie weggeskuif van die verlossing wat

\footnotetext{
${ }^{8}$ Willem $\mathrm{J}$ van Zijl (a w:182-184). Hierdie werk is van groot belang om die teologies-godsdienstige dinkwêreld van die Voortrekkers te peil. Tog moet daarteen gewaak word om nie die teokratiesCalvinistiese visie van en met betrekking tot die strukturering van die samelewing uit die oog te verloor nie. Interessant is in Spoelstra (1963:22ev) die aanduiding dat alles en almal wat die beskaafde, intelligente en gestudeerde Engelsman of Hollander nie van die Afrikaner kan verstaan of kan peil nie, aangedui is as: primitief, vuil, hardkoppig, bevooroordeeld, dom, fundamentalisties en dies meer. Dit is merkwaardig hoe hierdie beskrywing van die Afrikaner wat nie voldoen aan die wisselende vereistes van die wetenskaplike geleerdheid of beskaafdheid of wat ook al, tot vandag toe voortduur.
}

9 Willem J van Zijl (a w:183). Daarby kan ook gelet word op die "omskakeling" van die reformasie na die ortodoksie. Dit word nogal uitvoerig behandel deur C Graafland in Theologia reformata, 30(1) van 1987. Daar kan ook gelet word op die invloed van die Aristotelies-bepaalde skolastiek op die Nadere reformasie en op Brakel.

$10 \mathrm{~W}$ à Brakel (1763:511). 
Christus gee na die verlossing wat die gelowige deur sy gehoorsaamheid en dankbaarheid moet bevestig. In hierdie dinkwêreld waar die gelowige deur sy dade sy geloof in God en sy verbondenheid aan Hom moet betoon, is die aflê van 'n gelofte, die verbintenis tot 'n duidelik omlynde daad-van-dankbaarheid, nie vreemd nie. Daar is voorbeelde daarvan in die Ou Testament, wat dikwels juis geliefd was omdat dit sulke duidelike aanwysings gee van wat gedoen moet word.

In Calvyn se teologie waar die regverdiging deur die geloof alleen in die sentrum staan, is die bogenoemde opvatting moeilik in te pas. In die Calvinistiese ortodoksie, veral waar dit al deur die Nadere Reformasie beïnvloed was, was dit vanselfsprekend. Daarom kan gestel word dat wanneer die teologies-godsdienstige lektuur van die Voortrekkers in ag geneem word en ook die omstandighede waarin hulle verkeer het, word die aflê van 'n gelofte aan God gladnie vreemd nie.

Hier moet in gedagte gehou word dat die jaar 1838 vir die Voortrekkers byna iets soos 'n rampjaar was." Aan die einde van daardie jaar het 'n kommando van minder as 500 man dit gewaag om die Zoeloes met 'n leër van ongeveer 36 regimente, dit wil sê so ongeveer 'n 30000 man, te konfronteer. Afgesien daarvan was die kommando daarvan bewus dat die sukses of mislukking van die kommando sou bepaal of die Voortrekkers 'n nuwe vaderland in Natal sou vind. Met die groot moord van Februarie 1838 was die kommando bewus van wat met die Trekkers in Natal sou gebeur as die kommando nie daarin sou slaag om sy doelwitte te bereik nie.

\footnotetext{
$"$ Vergelyk in hierdie verband Duvenage (1988:31-129). Omdat die geskiedenis in ons dag grotendeels onbekend is, word hierdie verwysing noodsaaklik. Tog is dit so dat omdat die Gelofte vir baie mense ' $n$ verleentheid geword het, word die geskiedenis nuut geïnterpreteer, gewoonlik sonder om al die feite in ag te neem. Dit is in ons dae normaal want politieke korrektheid bepaal gewoonlik die interpretasie van die geskiedenis.
} 
Daarom was dit nie vreemd nie dat Kommodant-Generaal Andries Pretorius geoordeel het dat die kommando die Here God se hulp moet vra in 'n veldtog teen so 'n oormag. Dit dan moontlik op grond van 'n aanwysing van Brakel wat lui: ${ }^{12}$

Zyn wy in noodt moet met bidden om verlossingen ende in onze beweegredenen ook dese gebruyken, dat wy lust hebben om den Heere met blydschap te dienen en den Heere te danken ende te verheerlyken als Hy ons zouden uytgeholpen hebben ende dat wy onze dankbaarheyd ook souden betoonen, met dit of dat te laten, te geven ofte doen.

Dat Pretorius die werk van Brakel geraadpleeg het, lyk baie waarskynlik want by Brakel word 'n raamwerk vir 'n gelofte gestel en die Gelofte van 1838 voldoen aan al die vereistes wat.daar gestel is. ${ }^{13}$ Die oorwig van waarskynlikheid dui daarop dat so iets die aflê van 'n gelofte, wat aan die einde van die $17 \mathrm{e}$ en die begin van die $18 \mathrm{e}$ eeu in die Nederlandse Calvinistiese ortodoksie bekend was, en nou in die negentiende eeu in die

12 Brakel (1763:508) vervolgens, stel die volgende:

a. ' $n$ gelofte is ' $n$ verbintenis aan God, “... de verbintenisse geschiedt niet alleen aen Godt, maar de gelofte selfs geschiedt aan Godt dat hy het gene hy belooft te doen ende te laten, Gode sal doen ende laten."

b. die tweede punt is dat die gelofte moet wees

- $\quad$ over een goede zake,

- moet van een particuliere zake zijn die wij in hare nature en omstandigheden kennen en waervan wy versekerd zyn dat wy se mogen en konnen doen. Hier beredeneer Brakel dan Ps 15:4.

- $\quad$ oor 'n saak wat binne die vermoë van die gelowige lê,

- nie vanweë "koopmanschap", asof 'n mens met God wil handel drywe nie. Die gelofte moet geskied "als een dankbaerheyt aan Godt", vergelyk Ps 50:14.

- Tenslotte word beklemtoon dat 'n gelofte wat afgelê word, ook nagekom moet word. Dan verwys Brakel na Ps 76:12, Di 23:21, Pred 5:4 en Ps 66:13-14.

Wanneer die gegewens oor die inhoud van die Gelofte van 1838 hiermee vergelyk word, dan blyk dit dat die Gelofte inhoudelik presies aan die vereistes wat Brakel stel, voldoen. Indien die bronne geraadpleeg word en Gerdener se rekonstruksie van die teks, dan stel die Gelofte van 1838:

1. indien die Here God die kommando sal beskerm en die vyand in hulle hand sal gee,

2. dan sal ons (= die Voortrekkerkommando = die Voortrekkergemeenskap in Natal) uit dankbaa-heid, drie dinge doen naamlik:

- die dag van die corwinning voortdurend soos 'n dankdag deurbring,

- 'n kerkgebou oprig waar dit die Here God mag behaag.

- dit alles aan hulle kinders/nageslag sal sê sodat hulle ook die gebeure sal herdenk,

3. sodat die eer van God gedien sal word.

${ }^{13}$ Dit is opvallend in ons dae dat die gelofte en die onderhouding daarvan al meer omstrede gemaak word. Dit hang waarskynlik saam met die groot verdelingslyn in die Afrikanervolk wat aanvanklik deur die Groot Trek aangedui is en gedurende die Engelse Oorlog van 1899-1902 sy beslag gekry het en daarna nog nooit weer oorbng is nie. 
Afrikaner se geskiedenis opduik om dan 'n vaste verwysingspunt in die Afrikaner se geskiedenis te word, uit Brakel afkomstig is.

Net so interessant as die optrede van die Voortrekkers was met die aflê van 'n gelofte is hulle optrede na die veldslag by Bloedrivier op 16 Desember 1838 . Hulle wend geen enkele poging aan om die Zoeloes verder te onderwerp of te koloniseer nie. ${ }^{14} \mathrm{Al}$ wat hulle gedoen het was om, volgens die Retief-Dingane traktaat, die deel van Natal te beset wat aan hulle toegesê was. Al wat hulle daarby gedoen het, was om skadevergoeding vir die verliese wat hulle gelei het, van die Zoeloes te eis. ${ }^{15}$ Verder het die Voortrekkers die dorp Pietermaritzburg uitgelê waar die Gelofte-kerk gebou is. Die groot dryfkrag om die kerk gebou te kry was weer Komdt-Gen Andries Pretorius. ${ }^{16}$

Die onderhouding van die Gelofte na 1838 was aanvanklik nie in die vorm van jaarlikse openbare byeenkomste op 16 Desember nie. Moontlik het dit saamgehang met die feit dat Natal in 1843 deur imperiale Engeland geannekseer is. Dit het meegebring dat die groot meerderheid Afrikaners Natal verlaat het en hulle of in Oos-Transvaal se wêreld of in die Noord-Vrystaat hervestig het. Daar was dit nie vanselfsprekend dat die Gelofte onderhou sou word nie. Die dag is aanvanklik egter wel deur enkelinge elke jaar onderhou soos byvoorbeeld deur Erasmus Smit wat byeenkomste by sy huis gehou het. Dit is ook bekend dat Sarel Cilliers met sy vriende en bure op 16 Desember bymekaargekom het. ${ }^{17}$

In Natal het daar, vanweë die bemoeiing van ds D P M Huet en ds F L Cachet, 'n breër belangstelling gekom vir die onderhouding van die Gelofte. Dit gebeur as die

\footnotetext{
14 Vergelyk Liebenberg (1977:66-108, 296-297). Daar kan op gewys word dat die Voortrekkers en die Republikeinse Afrikaner ' $n$ eiesoortige houding teenoor hulle teenstanders openbaar het. Dit is opvallend dat die Afrikaner nooit ' $n$ haatdraende houding teenoor hulle teenstanders gehad het nie. Dit is nogal anders as die gewone optrede van die Zoeloes teenoor hulle teenstanders soos gesien kan word uit hulle optrede teen die Voortrekkers in Februarie 1838. Die meer algemene optrede van die swart volkere kan waarskynlik afgelees word uit hulle optrede met die difagane - vergelyk Duvenage (1986:63-69). Net so kan die kwaliteit van die Engelse imperialisme gemeet word aan hulle manier van oorlogvoer gedurende die Engelse Oorlog van 1899-1902.
}

15 B J Liebenberg (1977:296). Dit is 'n oop vraag of dit die Voortrekkers se bedoeling was om net die Geloftekerk in Pietermaritzburg op te rig of om oral waar hulle gekom het, 'n kerkgebou op te rig. Die pionier-Afrikaner se gewoonte om by die uitleg van 'n dorp te begin met die uitmeet van 'n kerkplein, is 'n baie ou gewoonte van die Westerse beskawingswêreld.

16 Buchner (1993:44-45).

${ }^{17}$ Büchner (1993:45). 
sinode van die Natalse NG Kerk in 1864 besluit dat 16 Desember in alle gemeentes "godsdienstig als een dankdag" herdenk moet word. ${ }^{18}$ Daarna het ds F L Cachet op 16 Desember 1866 die eerste maal op die Bloedrivierterrein 'n herdenkingsgeleentheid gehou. Daar is toe 'n godsdiensoefening gehou, 'n herdenkingstoespraak en vertellings deur mense wat aan die slag deelgeneem het. So kry die dag 'n duidelike kulturele en godsdienstige karakter. ${ }^{19}$ Met hierdie geleentheid is daar 'n klipstapeling gehou op die plek wat so min of meer as die middel van die walaer van 1838 beskou is.

Die herdenking van 16 Desember en die onderhouding van die Gelofte het ook in die ZAR en die OVS formeel aandag gekry. Op 3 Junie 1865 het die Volksraad van die ZAR besluit: ${ }^{20}$ "Tevens dat ieder jaar, den 16den December, als een algemene dankdag, dankbaar en den Heere gewyd, zal gevierd worden, ter gedachtenis dat de Emigranten, onder Gods zegen, van onder het juk van Dingaan zich vrygevochten hebben." Dit het egter nog nie beteken dat 16 Desember algemeen gevier is nie. Dit het eers heelwat later die karakter van 'n volksfees gekry. Tog was dit van die begin af duidelik dat die Gelofte van 1838 en die verpligting wat daar aanvaar is, gesien is as ' $n$ verpligting wat op die volk gerus het wat as gevolg van die slag van Bloedrivier in Natal staatkundige vryheid verwerf het. Dit is duidelik, ook deur die besluit van die Volksraad in 1865, dat die verpligting om die Gelofte van 1838 na te kom, die hele Voortrekkergemeenskap gegeld het en nie net die fisiese nageslag van Komdt-Gen A W J Pretorius en sy kommando of net die Natalse Voortrekkers nie.

\footnotetext{
${ }^{18}$ Die opvallende hier is die gemak en vanselfsprekendheid waarmee die diens van God en die kultuur van die mens bymekaargevoeg word om die Gelofte van 1838 na te kom.

${ }^{19}$ Breytenbach \& Joubert (1953:73).

20 Van Zyl (1977). Hier kan ook gelet word op die sorgvuldige navorsing wat in hierdie verband gedoen is deur ds K D Papp (1991:7-11; kyk ook Papp (1995:189-206). Hy wys daarop dat die Paardekraal-Gelofte van 1880 eerder aangedui moet word as die Wonderfontein-ooreenkoms of die Verbond van die burgers (Papp 1995:194). Wat wel op Paardekraal plaasgevind het, was 'n klipstapeling wat gesien is as 'n sigbare teken van die hernuwing van die Bloedriviergelofte. Daaraan is die Wonderfontein se Verbond van die burgers gekoppel. Ds Papp (1995:206): "Want Paardekraal getuig ... van die strewe van 'n vryheidsliewende volk wat sy vryheid en selfstandigheid nie prysgegee het nie, maar dit selfs teenoor ' $n$ wêreldmag verdedig het."
} 


\title{
3. DIE VERBREDING VAN DIE VERPLIGTING VAN DIE GE-
}

\section{LOFTE VAN 1838}

Die Gelofte van 1838 het 'n nuwe aanvaarding gevind in die volksbeweging wat in die ZAR ontstaan het na die anneksasie van die ZAR in 1877 deur Engeland: ${ }^{21}$ Dit word netjies uiteengesit deur president S J P Kruger wat in 1891 by die feesviering te Paardekraal gesê het: ${ }^{22}$

\begin{abstract}
Nou gaan ek die verdere wording en ontwikkeling van die Republiek verby tot op die tydstip waarop die Gelofte van 1838 weer hernu is. Gedurende die jare ( $d$ w s 1838-1880) het voorspoed en teëspoed mekaar afgewissel en onder alle afwisselinge is die plegtige Gelofte van 16 Desember te Bloedrivier weer uit die oog verloor. Die so dierbaar verkreë skat is nie meer beskou as ' $n$ dierbare skat van vryheid, as deur Gods hand geskenk nie. Die Gelofte van 16 Desember is nie trou volbring nie waaroor daar donker dae oor ons gekom het, sodat ons, toe God ons weer die vryheid gegee het, die vryheid dierbaar mog ag en tot ' $n$ erkentenis gelei mog word dat ons sterkte alleen in God is. En so het ons in hartsbenoudheid bymekaargekom, alle kwessies en belange van die boerdery uit die oog verloor en huis en hof veil gehad. Die oog was op God gevestig om in Hom sterkte te soek, en God het andermaal gehelp, die vryheid is teruggekry en die staat is herstel.

Hier, toe ons in benoudheid verkeer het, het elkeen sonder dat die regters daartoe bevel gegee het, 'n klip opgeneem en dit op hierdie plek gegooi as 'n gedenkteken tussen ons en die Here. Daarmee is die Gelofte van Bloedrivier hier hernu. Hy bring ons nou ter rug op dieselfde tyd waarop die Gelofte afgelê is.
\end{abstract}

In die klipstapeling by Paardekraal is op 'n fisiese manier die hernuwing van die Gelofte van 1838 bevestig. Daarmee is betuig dat die burgers geglo het dat die vryheid en wat daarmee saamgaan, genadegawes van die Here God was en nie, in die eerste plek,

\footnotetext{
${ }^{21}$ Du Plessis (1952:95). Dit is nodig om pres Kruger se herinnering te kontroleer met die vasstelbare feite. Belangrik egter in Kruger se uitspraak is sy interpretasie van die gebeure.

22 In hierdie verband is die mededelings van W J Leyds (1906:320ev) van belang (vgl ook Jorissen 1879:60ev).
} 
prestasies van die mens nie. Daarom verwys president Kruger na "die dierbare skat van vryheid as deur Gods hand geskenk" en was dit vir hom vanselfsprekend dat deur verootmoediging, gebed en hernuwing van die Gelofte van 1838, die volk van die ZAR sou vra vir die herstel van die vryheid. ${ }^{23}$

Saam met die hernuwing van die Gelofte van 1838 was die klipstapeling by Paardekraal ook 'n bevestiging van die Verbond van die burgers wat by die volksvergadering van Wonderfontein in 1879 die eerste maal na vore gekom het. ${ }^{24}$ Dit bly opmerklik dat die godsdienstig-teologiese dink- en leefwêreld waaruit die Gelofte van 1838 ontstaan het, 'n veertig-vyftig jaar later nog steeds 'n sterk rol gespeel het. Dit blyk onder andere uit ' $n$ opmerking oor 'n Geloftedagtoespraak in 1898 by Bronkhorstspruit: ${ }^{25}$

${ }^{23}$ Die teks van die Verbond word gegee in De Zuid-Afrikaan en Volksvriend van 15 Februarie 1879 en by W J Leyds (1906:294; kyk ook Papp 1995:192). Papp is van mening dat hierdie Verbond wat soms ook die Paardekraal-Gelofte genoem word, nie veel meer was as “... 'n ooreenkoms van 'n onbekende aantal mense wat van 10-13 Januarie 1879 op Wonderfontein vergader het." Omdat die teks van die verbond ook nie in die notule van die vergadering voorkom nie, oordeel Papp dat die verbond maar 'n sydelingse saak was en is. Dit is egter ' $n$ vraag of dit ' $n$ geregverdigde afleiding is. Verskillende belangrike gebeurtenisse het by Wonderfontein en Paardekraal gebeur wat nie in die notules genoem word nie, byvoorbeeld dat die klipstapeling by Paardekraal ook 'n hemuwing van die Gelofte van 1838 was, soos pres Kruger dit stel. In 'n skrywe van ds D van der Hoff aan die Patriot van 6 Mei 1881 (in Papp 1995:196-197) stel ds van der Hoff dat die klipstapeling “... 'n gedenkteken gewyd aan ons verbond dat wij met elkander in den naalm des Heeren gesloten hebben" (vgl ook die uitvoerige mededeling van H J C Pieterse aangehaal deur Papp 1995:198-199). Hierdie gegewens dui daarop dat daar beslis ' $n$ verbond van die burgers bestaan het. Dat dit nie in die amptelike stukke vermeld word nie, kan nie beteken dat dit sommer net 'n eenkant-gebeure was nie. Daar is voldoende getuienis dat die Wonderfonteinooreenkoms in en deur die klipstapeling by Paardekraal herbevestig is en dat dit as ' $n$ verbond van die burgers beskou is waar hulle hulleself aan mekaar verbind het om saam te stry vir die herverkryging van die vryheid, God se genadegawe aan die volk.

${ }^{24}$ Du Toit Spies (red) (s a:152).

${ }^{25}$ Kyk à Brakel (1763:2lev) waar hy die vraag stel of die Ou Testament vir die Christene van die Nuwe Testament ' $n$ reël van leer en lewe is. à Brakel antwoord positief daarop maar laat blyk dat reeds in sy tyd die Ou Testament deur baie as nie meer geldig beskou is nie. à Brakel stel: "Het OT vervattet deselfde zaken, hetselfde Evangelium, soo dat het OT ende het NT een en deselfde syn ten opzichten van het wesen, de omstandigheden ende de maniere van bedieninge, alleen onderscheiden; het OT zach op Christus die komen soude en daerom wierde het door afbeeldingen en afschaduwingen bedient. Daer is maer eene Kerke, van het begin der werelt tot desselfs eynde, de boeken des OT zyn aen de Kerke tot een regel overgelevert soos dan ook aen de Kerke des NT selfs de ceremonien die ingestelt waren om maer voor een tydt gepleegt te worden, rakende ons in het NT niet om gepleegt te worden, maer om daer uyt de waerheyt, de wysheid Godts te zien en Christus in alle omstandigheden te beter te leeren kennen." Dit kan ook nuttig wees om te let op à Brakel se opmerking (1.26): “... soos dat alle Boeken [van die Heilige Skrif], soo des Ouden als des Nieuwen Testaments, ons verbinden te gelooven en te doen alles wat daer in van Godt te gelooven ende te doen, bevolen wordt, ende buyten dat niets mag voorgestelt worden om te gelooven of te doen." Hieruit blyk dat die Bybel verstaan is as gesaghebbende Woord van God waaraan die mens gehoorsaam moet wees. 
In minder dan zestig jaar waren ze [die Voortrekkers] een natie geworden, vechtend en zooals Hans Botha als slotsom van zichzelf zeide: zoo heb ik myn lang leven doorgevochten. Hoe nu de natie in stand houden? En dan was het maar een vermaning van al de sprekers, vasthouden aan het geloof en de taal der vaderen. Als Israel had de Heer ook hun natie geleid en geholpen. We, zoo spraken zij, zoeken oorzaken voor de Groote Trek, voor hun swerven. Wanneer we meenden dat we de oorzaak hadden, zooals die in de geschiedenisboeken neergeschreven is, dan bleek die reden toch altyd maar zwak. 't Was alleen de Heer die Zijn volk geleid had.

Hierdie aanhaling vat in ' $\mathrm{n}$ paar sinnetjies saam wat die Afrikaner aan die einde van die vorige eeu oor die geskiedenis geglo het. Terselfdertyd weerspieël dit 'n geloof en vertroue op God wat naby is om sy volk te red. Opvallend is hier dat, soos dit vanselfsprekend in die Calvinistiese ortodoksie was, daar nie 'n onderskeid gemaak is tussen die Ou en Nuwe Testament nie. Daarom kon hulle troos, krag en leiding uit die Ou Testament put waar God se direkte bemoeienis met sy volk duidelik beskryf word. Bewus daarvan dat hulle, vanweë die doop, deel van die verbondsvolk was, het hulle geleer en gelei deur Brakel en die ander oude schrijvers die Ou Testament as Woord van God gelees om daarin die reël van die geloof raak te lees. ${ }^{26}$

Die hernuwing van die Gelofte van 1838 by Paardekraal, die bevestiging van die Verbond van die burgers aldaar en die klinkende oorwinnings wat in die Eerste Vryheidsoorlog van 1880-1881 behaal is, het meegebring dat daarna elke vyf jaar op 16 Desember 'n staatsfees by Paardekraal gehou is. Daar het pres Kruger in 1881, 1891 en 1896 'n toespraak gehou. Die betekenis wat Geloftedag gehad het, het hy so omskrywe: "Hierdie fees is dus 'n godsdienstige fees wat aan God en nie aan die mens gewy word nie.

${ }^{26}$ Du Plessis (1952:92). 
Daarom moet ons daarna streef en wens om ons Geloftes te betaal en in Sy weë te wandel om hierdie fees waarlik as ' $n$ godsdienstige fees te vier. ${ }^{27}$

Op Geloftedag, so is geoordeel, was die volk verplig om die Gelofte waarmee die republikeinse Afrikaner homself aan die Here God en sy diens verbind het, na te kom. Op hierdie dankdag, soos 'n sabbat, is aan God die eer gebring vir die uitredding by Bloedrivier en ook tydens die oorlog van 1880-1881. Daardie uitredding was meer as net lyfsbehoud want dit het ook gegaan om die behoud van die Voortrekkerideaal en wat daarmee saamhang. ${ }^{28}$ So was Geloftedag vanaf 1880-1899 'n sentrale gedenkdag in die kalender van die republikeinse Afrikaner. Majubadag, op 27 Februarie, is ook jaarliks herdenk maar dit het nie dieselfde inhoud as Geloftedag gehad nie. Geloftedag was vanweë die Gelofte en God se beantwoording daarvan, 'n unieke dag in die kalender van die republikeinse Afrikaner.

\section{GELOFTEDAG IN DIE TWEEDE VRYHEIDSOORLOG, 1899- 1902}

Voor die Tweede Vryheidsoorlog is daar nie op 'n besondere samekoms, soos in 1838 en in 1880 , God se seën op die wapens van die Republieke gevra nie. Dit het nie beteken dat die gebed tot God nagelaat is nie. Inteendeel, aan die einde van die vorige eeu het die republikeinse Afrikaner nog grotendeels vanuit 'n Christelik-nasionale lewens- en wêreldbeskouing geleef. Vir die grootste deel van die volk was die Bybel en die geskrifte van die oude schrijvers die leesstof waaroor hulle beskik het en dit was die middele wat gebruik is om hulle koers deur die lewe te bepaal. Dit het 'n bepaalde lewensuitkyk en lewenstyl gekweek waarvan die inhoud miskien die beste afgelees kan word uit president Kruger se toesprake en standpunte. Dit kan ook teruggevind word by ander leiersfigure

\footnotetext{
27 Oor die inhoud van die Voortrekkerideaal kan gelet word op die studie van Engelbrecht (s a:130-164). S $P$ Engelbrecht wys daarop dat Van der Hoff in 1856 'n gedig geskryf het waarin hy die Voortrekkerideaal so omskryf:

"Maar neen, de vrijheid die door God ons is geschonken

$\mathrm{Zij}$ wordt nooit weer op nieuw in boei en dwang geklonken,

$\mathrm{Zij}$ is 't geschenk van God, zij is betaald met bloed,

Zij blijv' Uw erfenis, U onvervreembaar goed."

Daar kan ook gelet word op Van der Hoff se skrywe De Afrikaansche Patriot, 6 Mei 1881 .
}

28 Aangehaal by Van der Merwe (1921:255-256). 
in die gemeenskap. Soos in die slotwoorde van 'n toespraak van president MT Steyn in die Volksraad van die OVS op 27 September 1899. Daar het Steyn gesê:

Indien gij met mij verschilt, zegt het dan, God weet, in deze hachelijken tijd wil ik niemand influenceeren. Gij hebt het volk kunnen raadplegen, ik niet: doet zijn wil.

Denkt niet dat ik lichtvaardig over de zaak denkt. Ik weet wat het is voor twee swakke republieken om te strijden tegen het machtigste rijk dat de wêreld ooit gekend heeft, maar ik weet dat, indien het tot een oorlog moge komen, dat wij dan niet strijden voor het stemrecht maar voor het bestaansrecht van het Afrikaner volk. Onze zaak is recht. Ik heb het geloof, niets geschiedt zonder de wil van den Allerhoogste en dat $\mathrm{Hij}$, die onze vaderen zoo wonderbaarlijk heeft geholpen, zich over ons zal ontfermen. In ieder geval, Zijn wil geschiedde. ${ }^{29}$

Hieruit blyk dat die leiers tot die laaste so besig was om deur middel van diplomatieke aksies die oorlog te probeer vermy, dat daar nie 'n geleentheid was om 'n groot volksbyeenkoms te hou nie. Tog was ook, soos dit deurklink in president Steyn se woord, in die ZAR 'n gevoel dat 'n onregmatige oorlog deur Engeland op die ZAR afgedwing word. Daarom het die leiers nie kans gesien om deur toegewings die toekoms

\footnotetext{
29 Die hele aanloop na die Tweede Vryheidsoorlog word as bekend veronderstel. Ten oorvloede kan verwys word na McCord (1952:201): "After the war Chamberlain expressed the same views, and stressed the danger to British ambitions the growing wealth and influence of the Transvaal had been, which had made it impossible to allow the Republics and their nation further existence. For the sake of the Empire they had to be destroyed and their territory and nation made British. A nation and their home had to disappear into the British maw to satisfy their avarice for gold and territory, and lust for world power. For this every British pledge was violated and every hypocricy and falsehood practised to deceive the world about the real issue."
} 
van land en volk op die spel te plaas nie. Toegewing aan die kwaad sou alleen die kwaad versterk. Daarom is in Een Eeuw van Onrecht betoog: ${ }^{30}$

Die geregtigheid waarop Piet Retief hom beroep het toe ons vaders die Kaapkolonie vaarwel gesê het, en wăarop Joachim Prinsloo hom in die Volksraad van Natal beroep het toe Natal deur Engeland geannekseer is, die geregtigheid waaraan die burgers van Transvaal hul saak op Paardekraal in 1880 toevertrou het, bly onveranderlik en soos 'n rots waarteen die golwe van die Britse diplomasie uiteenspat.

Juis omdat die Republikeinse leiers gevoel het dat hulle die stryd aanbind vir vryheid en vir reg, was hulle oortuig daarvan dat die Here God hulle defensiewe oorlog teen die Engelse oormag sou laat slaag. Daarby was hulle oortuig dat die Here God hulle vryheid en vaderland aan hulle gegee het en dat dit hulle opdrag was om daardie kleinode tot die uitsterste toe te verdedig. Daarom was die oorlog in 'n sekere $\sin$ 'n oorlog in gehoorsaamheid aan die wil van God. Dit word onder woorde gebring deur pres $\mathrm{M} \mathrm{T}$ Steyn in 'n toespraak wat hy op 23 Januarie 1900 by Ladysmith gehou het. Daar het hy gesê: ${ }^{31}$

Die God van ons vadere het Hom weer aan ons geopenbaar. Hy veg aan ons kant. Daarom moet ons nie wyk nie, hoe groot die doodsgevaar ook al mag wees, maar, laat ons daaraan dink, dat net so min as die Here aan die luiaard wat nie wil werk nie, brood sal gee, net so min sal Hy ons in hierdie moeilike stryd die onafhanklikheid laat behou as ons weifel. God, onse God, alleen is

\footnotetext{
${ }^{30}$ Reitz (1899). Hierdie bekende apologie is die werk van die destydse Staatsprokureur van die ZAR, die latere Gen J C Smuts. Dit is egter onder die naam van die baie meer bekende Staatssekretaris, F W Reitz, gepubliseer. Die opvallende van hierdie geskrif is dat dit nie in die Christelik-nasionale idioom geskrywe is nie. Die verwysingsraamwerk is eerder die klassieke en die dinkwêreld van die Engelse akademiese gemeenskap. Dat hierdie verweerskrif in sy siening volkome korrek was, blyk uit 'n opmerking van Joseph Chamberlain in 1903 toe hy gesê het (McCord a w:201): "As long as the Transvaal was a separate state, it was naturally a focus for those wild aspirations for a South Africa entirely apart from British influence, and no longer under the British flag, which have now been repudiated by every man of influence and responsibility. ... The contest between a progressive and retrograde civilisation has been decided ...." Chamberlain het waarskynlik bedoel dat Engeland die "progressive civilisation" verteenwoordig het. As egter gelet word op die wyse waarop die Engelse leër in Suid-Afrika tekere gegaan het, is dit 'n oop vraag of daar van "civilisation" gepraat kan word (vgl Spies 1978).
}

31 Aangehaal deur Ackermann (1969:178). 
ons hulp, en alleen met Sy bystand kan ons seêvier. Broers, as ons vertroue op God behou, soos ons vaders gedoen het, sal daar geen nood wees nie. Sterwend selfs, kan ons dan nog oorwin.

Hierdie totale vertroue op God, wat 'n weerspieëling van die Afrikaner van daardie tyd se leef- en dinkwêreld was, was vir sommige van die buitelandse waarnemers wat saam met die Boere in die veld was, nogal merkwaardig. Dit blyk, onder andere, uit 'n opmerking van kaptein Carl Reichmann, die militêre attaché van die VSA by die Republikeinse magte. Hy skrywe: ${ }^{32}$

The religion was that of the Dutch Reformed Church with its strict creed, and almost the only books in the house were the Bible and the hymnal ... a deep, sincere religious sentiment permeated the whole nation, which in every walk of life sought for divine guidance in the Book of books. As may be expected from a people of that kind they were a sober-minded, simple folk, civil and hospitable, unassuming and not given to boastfulness, profanity or drunkenness. During my stay of seven months with them I never saw a drunken Boer, and the greatest piece of profanity I ever heard was the Dutch equivalent for 'Almighty' .... Their religious sentiment predominated in everything.

Die beskrywing van Reichmann wys hoe groot die invloed van die oude schrijvers was met hulle sterk aandrang op 'n bevindelike belewing van die geloof en die beoefening van die praktyk van godsaligheid. Die Calvinistiese ortodoksie met die bevindelike aksent van die oude schrijvers het aan die einde van die vorige eeu nog 'n groter aanvaarding gehad as wat meestal aanvaar word. Hierdie stelling kan deur 'n tweetal voorbeelde onderstreep word.

32 Reichmann (s a:240). Die waardering van die Amerikaner staan nogal in skrille kontras met die tekening van die Republikeinse Afrikaner wat in die Engelse pers gegee is. Van belang is hier die werk van Hobson (1901:39). 'n Interessante hoofstuk is die wat getitel is Christianity in Khaki. 


\subsection{Geloftedag, 15-16 Desember 1899}

Na die veldslag van Colenso op 15 Desember 1899 het Gen Louis Botha 'n telegram na Pretoria gestuur waarin hy gesê het: ${ }^{33}$ "De God onzer vaderen heeft ons heden een schitterende overwinning gegeven ... Ik kan met een dankbaar hart u en het Afrikaansche volk gelukwensen met deze schitterende overwinning ...." Die lang telegram word afgesluit met die versoek: "Beleefd verzoek ik de Regeering om bij proclamatie eene algemene biddag te proclameren om Hem te danken, die ons deze overwinning gaf ...." Die bid- en dankdag is toe op 16 Desember gehou en weer was dit 'n dankdag vir 'n uitredding, 'n dankdag aan die Here God gewy omdat Hy sy hand oor die Republikeinse magte gehou het. Die dankdiens op die aand van 15 Desember asook op Geloftedag en die daaropvolgende Sondag was sober en saaklik. Dit was opmerklik omdat die burgers en volk van die ZAR ook die groot oorwinnings by Stormberg op 10 Desember en Magersfontein op 11 Desember kon gedenk. Dit was almal dankdae waar aan God die eer gegee is. ${ }^{34}$

J F Naudé wys daarop dat ook in die laer van die Waterberg en Heidelbergkommando 'n dankdiens gehou is en ook daar het dankbaarheid teenoor die Here God die toon aangegee. Nêrens was dar 'n teken van "vrolijke vermaak" nie. ${ }^{35}$ Jan F E Celliers wat op daardie stadium met 'n deel van die Pretoriakommando in die Suid-Vrystaat was, teken op 16 Desember 1900 onder andere in sy Oorlogsdagboek aan: ${ }^{36}$

... en toen moest ik de ingekomen neiuwstelegrammen voorlesen, onder anderen dat van de laatste groote overwinning bij Colenso; ik nam mijn hoed af toen ik het las en de heele schaar volgde mij daarin. Geen gejuich ging op, geen teken van geestdrift werd vernomen, maar het was als voelde men de stille plechtige dank opstijgen tot den Heer.

\footnotetext{
${ }^{33}$ Engelenburg (1928:33).

34 Breytenbach (1971:316).

35 Naudé (1903:75).

${ }^{36}$ Oberholster (red) (1978).
} 
Hieruit word tog iets duidelik van die Boere se belewenis van hulle afhanklikheid van God. Soos hulle dit ervaar, rig en bestuur die Here God alle dinge sodat 'n militêre oorwinning 'n genadegawe van God is, 'n neerlaag of 'n terugslag op sy beurt weer 'n beproewing of straf. So gesien is God nie 'n verre of vreemde God nie maar God wat naby is om soos 'n Vader sy hand oor sy kinders, sy volk te hou.

Hierdie siening het ook, aan die begin van die oorlog, die militêre strategie van die Boere beïnvloed in die sin dat ' $n$ suksesvolle veldslag nie opgevolg is nie. Dit kon, as die veldslag opgevolg word, die indruk skep dat die mens nie tevrede is met wat God toebedeel het nie en op sy eie nog meer wil behaal. Die siening van God as 'n God-vannaby was vir ' $n$ baie groot mate tiperend van die Nederlandse Calvinisme van die $17 \mathrm{e}$ en selfs die $18 \mathrm{e}$ eeu.

\subsection{Geloftedag, 15 en 16 Desember 1900}

'n Tweede Geloftedag wat gedurende die oorlog gedenk is, bevestig die beeld van die Geloftedag van 1899. Die Geloftedag is gedenk nadat die gesamentlike kommandos van Noord- en Wes-Transvaal op 13 Desember 1900 aan die suksesvolle veldslag by Nooitgedacht, wes van Pretoria, deelgeneem het. In hierdie veldslag is Generaal R A P Clements se magte oorrompel deur die goed gekoördineerde optrede van Generaal C F Beyers en Gen J H de la Rey. Die Engelse het nie net 'n swaar neerlaag gely nie, maar terselfdertyd het die Republikeinse magte weer moed geskep na 'n reeks terugslae.

$\mathrm{Na}$ die veldslag is Geloftedag op 16 Desember deur die Bocrekommandos herdenk terwyl heelwat vrouens en kinders uit die omgewing die verrigtinge bygewoon het. Oor die verloop van die gebeure berig J F Naudé: ${ }^{37}$

Ds [A P] Kriel trad nu op, hield een korte toespraak en las het verbond voor, dat wij zoo naauwkeurig mogelijk naar het oorspronkelijke hadden opgesteld, hetwelk te Bloedrivier gemaakt, te Paardekraal vernieuwd werd; en waar het gansche volk in betrokken was. Het verbond zou nog eens gelezen worden en daarna zou ieder die getrouw wilde zijn aan de oorspronkelijke gelofte, opstaan.

${ }^{37}$ Naudé (1903:195). 
Nadat die burgers op die manier die Gelofte herbevestig het, het verskillende sprekers oor die betekenis van Geloftedag gepraat. Generaal de la Rey wat oor Afrikanervryheid gepraat het, het gesê:

\footnotetext{
Telkemale vond de Afrikaander een plaats om heen uit te wijken ten einde vrij te zijn. In 1880 was er geen toevluchtsoord meer en daar te Paardekraal sloten de burgers met God en elkander een verbond en het gevolg was dat wij weer een vrij volk werden. Dat verbond hadden wij overtreden ... en moesten wij vernieuwen.
}

In dieselfde gees het Gen Beyers gepraat en na hom Gen J C Smuts en Komdt J C G Kemp. Daarna is as teken dat almal weer die verbond met God en mekaar aanvaar, 'n klipstapeling gehou. So het op Skimmelkop, naby Nooitgedacht, 'n klipstapel verrys wat deur ds AP Kriel Ebenhaezer genoem is.

\section{SLOTOPMERKINGS}

'n Paar gevolgtrekkings is tog moontlik na hierdie enigsins kursoriese oorsig. In die eerste plek is dit duidelik dat die Gelofte en die aflê daarvan in 1838 voortkom uit die Calvinistiese ortodoksie wat die denke en geloof van die Voortrekkers bepaal en inhoud gegee het. Dit is so dat die gedagte om 'n Gelofte af te lê by Komdt-Gen W A J Pretorius ontstaan het, maar dit is deur sowel Sarel Celliers as die hele Strafkommando aanvaar. As gevra word na die teologie waaruit die gelofte na vore kom, dan is dit die Calvinistiese ortodoksie soos dit met sy bevindelike inslag by, onder andere, Wilhelmus à Brakel gevind word. As die hoofstuk wat Brakel skrywe Vande Geloften (Dl 2, bl 508-512) vergelyk word met die beskikbare gegewens oor die aanvaarding en aflê van die Gelofte deur die Voortrekkers dan lyk die afleiding dat Brakel die Voortrekkers se teologiese leidsman in hierdie saak was, heeltemal billik. Die indruk word versterk as in ag geneem word hoe bekend Brakel se werk was in die wêreld waar Pretorius vandaan gekom het.

Dat Brakel buitendien bekend was onder die pionier-Afrikaners gedurende die laaste dekades van die vorige eeu, blyk uit verskillende gegewens. In die eerste plek het die Algemene Kerkvergadering van die Ned Hervormde Kerk in 1857, met die 
aanvaarding van 'n Kerkwet, besluit om saam met die Kerkwet “... eenige bepalingen aangaande de magt der politieke overheid, achter die wetten (= die Kerkwet) te doen drukken, en wel volgens hetgeen men daarvan vindt in W a Brakel. ${ }^{38}$ In die tweede plek kan daarop gewys word dat ds Dirk van der Hoff op 28 April 1859 in die Algemene Kerkvergadering verwys het na "... de vooral hier zoo hoog geroemde W v Brakel ...."

Ten oorvloede kan gesel word dat die ander oude schrijvers wat baie gelees en geraadpleeg is, nie een so eksplisiet soos Brakel oor 'n sak soos 'n gelofte en sy onderhouding handel nie. Wat egter wel waar is, is dat die ander oude schrijvers dieselfde teologies-godsdienstige insigte as Brakel uitdra, dat hulle ook die klem op die ortopraksis lê wat sonder terughoudendheid die regte leer van die ortodoksie aanvaar. Want daar is nie 'n leerstellige afstand tussen die Nadere Reformasie en die ortodoksie nie. Die Nadere Reformasie wil slegs deur die aksent effens te skuif weg van die sentrale leerstuk van die regverdiging deur die geloof alleen na die ordo salutis en die ervaringbevinding van die gelowige, die regte lewenstyl coram Deo bevorder.

Met die aflê van die Gelofte gebeur dit ook: 'n onderneming word gegee om uit dankbaarheid 'n bepaalde lewenskoers te gaan indien die Here God die uitredding in 'n noodsituasie sou skenk. Die enigste merkwaardige is dat by Wasbank-Bloedrivier en Paardekraal-Majuba die volk, wat egter as gedoopte verbondsvolk verstaan word, aan daardie Gelofte gebind word. As sodanig is die Gelofte iets eiesoortig van die Afrikaner. Die opvallende in die saak, sowel by die aflê van die Gelofte in 1838 as by die herbevestiging daarvan in 1880 , is dat dit plaasgevind het sonder die hulp en advies van predikante. Daarom is dit waarskynlik die billikste om af te lei dat vir die verstaan van die teologies-godsdienstige dinkwêreld waaruit die Gelofte en sy onderhouding voortgekom het, nie verder gesoek hoef te word nie as die teologies-godsdienstige wêreld van die gewone gelowiges. Volgens die beskikbare getuienis is hulle opvattings hoof-saaklik bepaal deur die opvattings van die oude schrijvers, die verteenwoordigers van die Nadere Reformasie.

Dat die invloed van Brakel en die ander oude schrijvers in die twintigste eeu afgeneem het, hang waarskynlik saam met die feit dat gedurende die Tweede Vryheidsoorlog van 1899-1902 die Engelse leër ongeveer alle Boereplaashuise met hulle inhoud

\footnotetext{
${ }^{38}$ Gerdener (1930:239 en 222).
} 
verbrand het. Dit beteken dat ook al die teologies-godsdienstige boeke vernietig is. Na die oorlog was hierdie boeke nie meer beskikbaar nie en so het die invloed van die oude schrijvers gestaan.

Verder wil dit voorkom dat die Gelofte van 1838 , veral vanaf 1880 , verstaan is as 'n simbool van die Here God se beskerming van die republikeinse Afrikaner aan wie Hy vryheid en 'n eie vaderland gegee het. Daardie oortuiging het op die Afrikaner die verpligting gelê om self alles in sy vermoë te doen om die vryheid en die vaderland wat God gegee het, te bewaar en te beskerm. Dit is die agtergrond van die Verbond van die burgers van 1880 . Daardie verbond is nie 'n bykomende Gelofte by die 1838 -Gelofte nie maar ' $n$ onderlinge verbond van die burgers in die trant van die Skotse covernants van die 16 e eeu. ${ }^{39}$

Die algemene aanvaarding van die Gelofte van 1838 en die Verbond van die burgers van 1880 het waarskynlik meegebring dat die owerhede in die ZAR in die negentigerjare geoordeel het dat dit nie nodig is om weer ' $n$ volksbyeenkoms soos by Paardekraal in 1880 te hou voordat Engeland die oorlog aangesê moes word nie. Die jaarlikse nakoming van die Gelofte van 1838 het die betekenis daarvan buitendien lewendig gehou. Dat die Gelofte van 1838 gedurende die oorlog onderhou is, onderstreep die mening dat die Gelofte dan reeds vir die Afrikaner 'n simbool geword het van die volk se besondere verband met en verpligting teenoor die Here God. Hierdie geloof is gevoed deur die teokratiese aksent in die Calvinistiese ortodoksie.

Die onderhouding van die Gelofte en die instandhouding van Geloftedag kry in die twintigste eeu 'n reeks nuwe aksente wat oor die algemeen die waardering vir Geloftedag verhoog het. Maar dit is 'n saak wat nie nou hier behandel kan word nie. Samevattend kan gestel word dat die Gelofte van 1838 veral deur die herbevestiging

\footnotetext{
39 Kerr (1895:131). Wanneer die teks van die bekende Solemn League and Covenant van 1648 nagelees word, is dit opvallend dat die argument wat gevoer word in die Verbond van die burgers nogal in dieselfde patroon loop. Opvallend is die Exhortation wat gehou is in die House of Commons net voor die Parlement en die Westminster Assembly die Solemn League and Covenant aanvaar het. Daar word gesê: "We deal with God as well with man, and with God in His greatness and excellencey, for by Him we swear; and at the same time we have to do with God and His goodness, Who now reached out unto us a strong and seasonable arm of assistance. The goodness of God procuring succour and help to a sinful and afflicted people." Dit is ' $n$ interessante aanduiding van die teologie waarin die Covenant moontlik was. Dit verskil nie wesenlik van die teologie van die Voortrekkers waaruit sowel die Gelofte van 1838 as die Verbond van die burgers voorgekom het nie.
} 
daarvan deur die burgers by Paardekraal en die toevoeging van die Verbond van die burgers, wat gevolg is deur die reeks oorwinnings van die Eerste Vryheidsoorlog van 1880-1881, in die 19e eeu die Gelofte uit die byna-vergetelheid geruk het. Deur die groot oorwinning by Majuba, 27 Februarie 1881, het die Gelofte 'n nuwe betekenis gekry en 'n inspirasie gebly vir die burgers van die ZAR wat hulle volksvryheid en die eie vaderland as gawes van die Here God self waardeer het.

Die Gelofte van 1838 wil tot in 'n hoë mate dieselfde sê as die gebed van Huldrych Zwingli wat by die ingang van die Grossmünster in Zürich geskryf staan: "Verschaffet dass das Gottlich Wort trauwlich by üch gepredigt werde - damit werdend ir uwer Vatterland behalten - und obs glych dem Tufel leid war - Denn wo Gotsforcht itst Da ist die Hilff Gottes."

\section{Literatuurverwysings}

à Brakel, W 1763. Logike Latreia, dat is redelijke Godtsdienst, Deel 2. Rotterdam: Wed Hendrik van der Aak.

Ackermann, W H 1969. Opsaal. Johannesburg: Voortrekkerpers.

Bantjes, J G 1839. Journaal. De Zuid-Afrikaan 14 Junie 1839.

Breytenbach, J H 1971. Die Geskiedenis van die Tweede Vryheidsoorlog in Suid-Afrika 1899-1902, Deel 1. Pretoria: Die Staatsdrukker.

Breytenbach, J H \& Joubert, D C 1953. Notule van die Volksraad van die SuidAfrikaanse Republiek, Deel 5. Kaapstad: Die Staatsdrukker.

Büchner, E P 1993. 'n Dankdag soos 'n Sabbat. MTh-skripsie, Universiteit van die Oranje Vrystaat.

De Afrikaansche Patriot 6 Mei 1881.

De Hervormer, 15 December 1909.

De Hervormer, 15 December 1910.

De Hervormer, 15 Februarie 1911.

De Zuid-Afrikaan 15 Februarie 1979.

Du Plessis, J S 1952. President Kruger aan die Woord. Bloemfontein: Sacum. 
$\mathrm{Du}$ Toit Spies, F J (red) s a. Briewe uit Transvaal van $G A A$ Middelberg. Pretoria: SAAWK.

Duvenage, G D G 1986. Die Groot Trek: Die eerste drie jaar, Deel 1. Pretoria: Die Afrikanervolkswag.

- 1988. Die Groot Trek: Die eerste drie jaar, Deel 3. Pretoria: Die Afrikanervolkswag. Engelbrecht, S P s a. Ds Dirk van der Hoff en die Voortrekkerideaal. HTS 9, 130-164.

Engelenburg, F F 1928. Genl Louis Botha. Pretoria: Van Schaik.

Gerdener, G B A 1930. Boustowwe vir die geskiedenis van die NG Kerk in die Transgariep. Kaapstad: Naspers.

Graafiand, C 1987. Theologia reformata 30(1).

Hanekom, T N 1951. Die liberale rigting in Suid-Afrika: 'n Kerkhistoriese studie. Stellenbosch: CSV.

Hobson, J A 1901. The psychology of Jingoism. London: Grant Richards.

Jorissen, E J P 1879. Transvaalsche herinneringen 1876-1896. Amsterdam-Pretoria: De Bussy.

Kerr, J 1895. The Covenants and the Covenanters. Edinburgh: $\mathrm{R} W$ Hunter.

Krüger, D W 1960. South African parties and policies. Cape Town: Human \& Rousseau.

Leyds, W J 1906. De eerste annexatie van de Transvaal. Amsterdam: P Allert de Lange.

Liebenberg, B J 1977. Andries Pretorius in Natal. Pretoria-Kaapstad: Academica.

McCord, J J 1952. South African struggle. Pretoria: De Bussy.

Naudé, J F 1903. Vechten en vluchten met Beyers en Kemp bokant De Wet. Rotterdam: Nijgh en Van Dittmer.

Oberholster, A G (red) 1978. Oorlogsdagboek van Jan F E Celliers 1899-1902. Pretoria: RGN.

Papp, K D 1991. Die Ned Hervormde Gemeente Krugersdorp 1891-1991. Krugersdorp:

Die Kerkraad van die Nederduitsch Hervormde Gemeente Krugersdorp.

- 1995. Die oorsprong van die Paardekraal-Gelofte. HTS 51(1), 189-206.

Pont, A D s a. Enkele aantekeninge by die teologies-godsdienstige gedagtes van sendeling S J G Hofmeyr, 1839-1905. HTS 14.

Preller, G S 1918. Voortrekkermense, Deel 1. Kaapstad: De Nationale Pers.

Spies, S B 1978. Methods of barbarism. Cape Town: Human \& Rousseau. 
Spoelstra, B 1963. Die "Doppers" in Suid-Afrika 1760-1899. Kaapstad: Nasionale Boekhandel.

Reichmann, C s a. Boer War operations in South Africa 1899-1901. Johannesburg: Scripta Africana.

Reitz, F W 1899. Een eeuw van onrecht. Pretoria: Bienedell.

Van der Merwe, N J 1921. Marthinus Theunis Steyn: 'n Lewensbeskrywing. Kaapstad: De Nationale Pers.

Van Zijl, W J s a. Van skeepskis na wakis na boekrak. Kaapstad: Lux Verbi.

Van Zyl, M C 1977. Die protesbeweging van die Afrikaners 1877-1880. PretoriaKaapstad: Academica.

Volksvriend 15 Februarie 1879. 